\title{
Book Review: Rediscovering the Natural Law in Reformed Theological Ethics - By Stephen J. Grabill
}

William S. Brewbaker III

University of Alabama - School of Law, wbrewbak@law.ua.edu

Follow this and additional works at: https://scholarship.law.ua.edu/fac_working_papers

\section{Recommended Citation}

William S. Brewbaker III, Book Review: Rediscovering the Natural Law in Reformed Theological Ethics - By Stephen J. Grabill, (2008).

Available at: https://scholarship.law.ua.edu/fac_working_papers/357

This Working Paper is brought to you for free and open access by the Faculty Scholarship at Alabama Law Scholarly Commons. It has been accepted for inclusion in Working Papers by an authorized administrator of Alabama Law Scholarly Commons. 


\title{
THE UNIVERSITY OF ALABAMA SCHOOL OF LAW
}

\author{
Book Review: \\ Rediscovering the Natural Law \\ in Reformed Theological Ethics. \\ By Stephen J. Grabill
}

WILLIAM S. BREWBAKER III

Journal of Law and Religion, Vol. XXIII, No. 1 (2007-08)

This paper can be downloaded without charge from the Social Science Research Network Electronic Paper Collection: http://ssrn.com/abstract=1117959 
Reprinted with the permission of the Journal of Law and Religion from Vol. XXIII No. 1 (2007-08).

REDISCOVERING tHE NATURAL LAW IN REFORMED THEOLOGICAL ETHICS. By Stephen J. Grabill. William B. Eerdmans Publishing Company 2006. Pp. 310. \$38.00. ISBN: 0-802-86313-2.

One of the pleasant surprises of the last thirty years has been the development of increasingly warm relations between American evangelical and Catholic Christians, and one of the positive consequences of improved relations has been increased opportunities for scholarly dialogue between the two traditions. As Mark Noll has recently argued, evangelical-Catholic engagement enhances Christian learning because each side needs what the other has to offer: Evangelicals have tended toward disinterest in history and the material world, and disengagement from the wider tradition of Christian thought and they have a tendency to over-divide the world into good and evil. Catholics, on the other hand, have sometimes given too much place to created nature as opposed to divine grace, emphasized catholicity and tradition to the relative neglect of Scripture, and shown "too great a willingness to find truth, beauty and goodness spread at large in the world." ${ }^{1}$

Noll's assessment is especially apt when it comes to legal scholarship. In particular, evangelical legal scholarship has suffered from a lack of connection with the larger Christian tradition. ${ }^{2}$ One reason for the disconnection has been that historically, Christian thinking about law has largely centered around natural law. Thomas Aquinas' Treatise on Law is arguably the pre-eminent account of natural law, and evangelicals have tended to be suspicious of both Thomas and the natural law project. A typical caricature of the "scholastic" St. Thomas is that his Aristotelianism runs away with his theology, ${ }^{3}$ and evangelicals frequently associate the natural law tradition with aspects

1. Mark Noll, Reconsidering Christendom?, in Evangelicalism, Catholicism and the Future of Christian Learning (Thomas Albert Howard ed., Baker forthcoming 2007).

2. See generally William Brewbaker, Who Cares? Why Bother?: What Mark Tushnet and Jeff Powell Have to Say to Each Other, 55 Okla. L. Rev. 533, 551-557 (2002).

3. For a critique of evangelical assessments of Aquinas written by a Protestant, see generally Arvin Vos, Aquinas, Calvin and Contemporary Protestant Thought (Christian U. Press 1985). 
of Catholic theology that, in their eyes, neglect the Scriptures in favor of philosophy and fail to take seriously enough the noetic effects of sin. Small wonder, then, that the natural law tradition has had limited influence in evangelical circles.

Stephen Grabill's ambitious, erudite new book intends to change all that. Indeed, his stated aim is "to assist contemporary Protestant pastors, denominational officials, theologians, ethicists, public intellectuals, seminarians, graduate students and general readers to rediscover and rehabilitate natural law and related doctrinal concepts." (2) While he is at it, Grabill challenges some important Catholic misperceptions about Protestant theology as well. More specifically, Grabill's purposes are to explain why Reformed Protestants are so skeptical of the natural law tradition and to argue that such skepticism ought to be seen as an aberration within the historical theology of the magisterial Reformation. Although it is not an explicit goal of the book to articulate "a contemporary doctrine of natural law that could be integrated seamlessly into the larger body of Reformed dogmatics” (17), Grabill's historical-theological analysis is highly suggestive as to the form such a doctrine might take.

Karl Barth casts a long shadow in Grabill's book. Although modern Protestant skepticism about natural law is due in part to the "anti-scholastic, anti-metaphysical accents of nineteenth-century German liberal theology," and in part to its association with Roman Catholic moral theology (4), ${ }^{4}$ Barth's influential attacks on natural theology and natural law get the most attention in Grabill's argument. Specifically, Grabill takes aim at Barth's famous epistemological attack on natural theology in his 1934 debate with Emil Brunner and at Barth's "discontinuity thesis"-Barth's claim that "the orthodox Protestant theologians of the sixteenth and seventeenth centuries had unwarrantably converted the Reformers' pastorally oriented and exegetically based ethics into the abstract scholastic precepts of naturallaw theory."(12) In large measure, the book's argument is organized around two claims: (i) that Barthian radical epistemological skepticism is out-of-step with the teaching of the magisterial Reformation, which has always left room for affirmative (but limited) uses of natural revelation, natural theology and natural law; and (ii) that there is substantial intellectual continuity between late medieval philosophical realists, the early Reformers (including Calvin) and the later "Reformed

4. "Protestant intellectuals... have typically regarded the natural-law tradition to be doctrinally and philosophically tied to Roman Catholicism, and thus open to the standard Protestant criticisms that Rome does not take either sin or history seriously enough.” (4). 


\section{BOOK REVIEW}

scholastics.”

One of the book's many strengths is the care with which Grabill defines the terms that have historically marked theological disputation over natural law. His historical argument begins with the emergence of nominalism and voluntarism in late medieval theology. Rejecting " $t$ the supposition that Protestant theology and nominalist metaphysics are fundamentally wedded” (55), he is careful to distinguish between Occam's nominalism and Scotus' voluntarism. Although the Reformers gave priority to the will of God, Grabill argues, the main contours of Reformed thought are compatible with philosophical realism, and the Reformers reject the view that God is an arbitrary legislator. In order to set the stage for the vindication of these claims, he identifies two main types of natural law theories in late medieval scholasticism-“a realist theory of natural law, represented by-among others-Thomas Aquinas and Duns Scotus, and a nominalist theory of natural law, represented by_among others_William of Occam and Pierre d'Ailly.” (57) Significantly, he concludes that "the opposite of a realist natural-law theory is not necessarily a divine command theory ... but rather a nominalist natural law theory.” (57) He also argues that the dialectic of the two divine powers (God's absolute power vs. God's ordained power) that preoccupied late medieval theologians "was not intended to present a theory of divine action but to affirm the contingent nature of the created order.” (64)

Having provided a broad backdrop of the relevant medieval theological controversies, Grabill next argues, contra Barth, that Calvin's theology is generally compatible both with some versions of late-medieval realism and with the theology of the orthodox Reformed scholastics who came after him. Grabill acknowledges that "Calvin leaves much unstated about natural law in comparison to his medieval predecessors' and Reformed successors' treatments of the subject....”

(91) He nevertheless concludes that

Calvin follows the realist tradition (most likely in its Scotist trajectory ...) in its affirmation of the ontological status of moral knowledge...., but differs with it epistemologically, meaning in the degree to which unaided reason can adequately apprehend precepts of the natural moral law. (91)

Grabill draws on Calvin's teaching that God can be known as Creator without being known as Redeemer to preserve a positive place for natural moral knowledge with respect to civil, social and economic ordering. (72)

In the succeeding chapters of the book, Grabill uses the thought of 
Peter Martyr Vermigli, Johannes Althusius and Francis Turretin to show the fundamental continuity between Calvin's thought and that of other Reformers and, where such continuity is lacking, to question Calvin's status as "chief codifier" of the Reformation. Vermigli (1499-1562) was an older contemporary of Calvin's. Grabill (following Richard Muller) characterizes Vermigli's "formulation ... of the knowledge of God as broadly Thomistic with a strong Augustinian accent.” (102). Calvin's account of natural revelation, on the other hand, departs from that of both Augustine and Calvin's Protestant contemporaries "by distinguishing sharply between what is offered to natural reason and what is received." $(113)^{5}$ Vermigli held that God's natural revelationthough partial and inadequate for salvation-was "perceived by fallen human beings, who, precisely because of their sinfulness, proceed to suppress, distort, deny, ignore, forget and abuse what they know.” $(114)^{6}$ While Calvin did not hold that natural revelation was inevitably and entirely misperceived, he did not adopt the relatively unproblematic idea of reception that Vermigli carried over from Augustine. In Grabill's story, the Thomist-trained Vermigli offers a Reformed account of natural law that, though still undeveloped, is somewhat more philosophically sophisticated and optimistic than Calvin's.

Johannes Althusius' (1557-1638) political and legal theory was developed between the Reformation itself and the period of "high orthodoxy" emblematized by Francis Turretin. Althusius is, at first blush, an unusual choice for a book about natural law, because he is best known for his emphasis on covenant, federalism and biblical law. Grabill argues, however, that

for Althusius, like Reformed Orthodoxy in general, the moral law of the Decalogue is simply a renewed and re-enforced form of the logically prior lex naturalis, the universal knowledge of morality God originally implanted in the mind at creation, but which after the fall has become obscure and difficult to discern with precision and reliability. (132)

In this view, and in his emphasis on the importance of prudence in making laws for particular societies, Althusius is indebted to the Italian reformer Jerome Zanchi (1516-90). Grabill argues that Althusius' work can only be properly understood in light of Zanchi's influence, particularly Zanchi's treatment of the types of law, which was itself influenced by Aquinas’ Treatise on Law. (132-142)

5. The quotation is from David Steinmetz, Calvin in Context 29 (Oxford 1995).

6. Again quoting Steinmetz, Calvin in Context 31. 


\section{BOOK REVIEW}

The last figure treated at length in the book is Turretin (1623-87), whose Institutio theologiae elencticae Grabill regards as "the crowning achievement of nearly a century and a half of Reformed theological development." (150) Grabill regards as unfounded the charge that Turretin's use of the scholastic method is alone enough to place him in discontinuity with the earlier Reformers. Rather, Turretin maintains essential theological continuity with the Reformers but methodological continuity (through scholasticism) with both some Reformers (e.g., Vermigli, Zanchi) as well as older scholastics such as Aquinas. (153) According to Grabill, Turretin finally develops the long-awaited Reformed doctrine of natural law that "is broadly affirmative of the realist natural-law tradition (the Thomist and Scotist trajectories)" and "is systematic and seamlessly integrated with the adjacent doctrines of natural revelation and natural theology.” (154)

As should be clear from the preceding account, Grabill has written an enormously ambitious book, charting a sophisticated line of argument that navigates a sea of theological, historical and biblical disputes. He does not hesitate to challenge the accepted wisdom of prominent medievalists, Calvin scholars and theologians of various stripes. No doubt Grabill's story will itself be challenged by scholars in each of these disciplines, but its credibility is greatly enhanced by his reliance on the work of Richard Muller, Heiko Oberman and David Steinmetz, to name but three significant scholars among many others.

While Grabill's thesis is important in its own right, the book's significance goes beyond its powerful argument for seeing considerable, though not complete, continuity between late medieval realists, the magisterial Reformers and their orthodox successors. Even if Grabill has not yet offered a contemporary Reformed dogmatics of natural law, he has more or less traced out the course that must be traversed for that to take place. In the book's conclusion he has also outlined an important story waiting to be told about the reasons natural law thinking ceased to be associated with Protestant theological orthodoxy and came to be seen as symptomatic of modernity. The book, with its meticulously documented source material, will be especially valuable to legal scholars attempting to engage natural law from the perspective of Reformation theology or to find common ground between Protestant and Catholic legal thought. Given the current renewal of interest in the relation between Christian theology and law, Rediscovering the Natural Law in Reformed Theological Ethics is an important work. 
William S. Brewbaker III

* Professor of Law, University of Alabama School of Law, Tuscaloosa, Alabama. 